\title{
KONSTRUKSI GENDER DALAM NOVEL-NOVEL ANAK KARYA PENULIS ANAK
}

\author{
Else Liliani \\ FBS Universitas Negeri Yogyakarta \\ email: else_l@uny.ac.id
}

\begin{abstract}
Abstrak
Penelitian ini bertujuan mendeskripsikan identitas, peran, dan relasi gender yang terdapat dalam novel anak. Sumber data penelitian ini adalah enam novel anak yang diterbitkan oleh Dar! Mizan. Keenam novel tersebut dipilih secara purposif. Data penelitian ditemukan dengan cara membaca novel berulang-ulang, dicatat dan diklasifikasikan berdasarkan kategori rumusan masalah. Data di analisis dengan kerangka kritik sastra feminis, yakni woman as a reader. Hasil penelitian sebagai berikut. Pertama, gambaran keadilan gender belum tampak karena masih ditemui stereotipisasi identitas gender. Tokoh yang memiliki dua karakter sekaligus, feminin dan maskulin, justru dideskripsikan sebagai tokoh yang aneh. Kedua, terdapat ketidakseimbangan dalam pembagian peran gender. Tokoh perempuan memiliki peran gender di sektor publik dan domestik, sedangkan tokoh laki-laki hanya berperan di sektor publik. Ketiga, relasi yang tercipta menunjukkan pola yang cukup variatif, namun dapat dikenali. Relasi ini akan berbeda bentuknya berdasarkan konteks, jenis kelamin, usia, kelas sosial, budaya, dan faktor keturunan.
\end{abstract}

Kata kunci: novel anak, konstruksi gender, identitas, peran, relasi

\section{GENDER CONSTRUCTION IN CHILDREN'S NOVELS BY CHILD WRITERS}

\begin{abstract}
This study aims to describe identities, roles, and gender relations in children's novels. The data sources were six children's novels published by Dar! Mizan.The six novels were purposively selected. The data were collected by repeatedly reading the novels, recorded, and classified based on the problem formulation categories. They were analyzed using the framework of feminist literary criticism, namely woman as a reader. The results of the study are as follows. First, gender equality has not been manifested because there is still gender identity stereotyping. Characters with two identities, feminine and masculine, are described as weird characters. Second, there is inequality in the distribution of gender roles. Female characters have roles in public and domestic sectors and male characters play roles in the public sector only. Third, existing relations show varied but recognizable patterns. The relations are manifested in different forms depending on contexts, sexes, ages, social classes, cultures, and descendant factors.
\end{abstract}

Keywords: children's novels, gender construction, identities, roles, relations

\section{PENDAHULUAN}

Sastra anak merupakan sarana yang potensial dan efektif untuk menyampaikan nilai-nilai sosial dalam masyarakat serta membangun konstruksi pemikiran pembacanya, termasuk konstruksi akan gender. Mengingat pentingnya fungsi bacaan pada anak, serta tujuan pemerintah dalam menciptakan suatu kesetaraan dan keadilan gender seperti yang tertuang 
dalam Instruksi Presiden RI No 9 Tahun 2010 mengenai pengarusutamaan gender, diperlukan adanya penelitian untuk mencermati, mengidentifikasi, serta memahami bagaimana konstruksi gender yang terdapat dalam novel anak,.

Penulis novel anak saat ini tidak hanya ditulis oleh orang dewasa, melainkan juga anak-anak. Asumsinya, konstruksi pemikiran para penulis anak mengenai gender akan lebih setara mengingat para penulis anak itu lahir di era masyarakat yang cenderung lebih demokratis dan lahir dari orang tua yang telah mengenyam pendidikan tinggi. Namun, dari observasi awal, masih ditemukan adanya stereotipisasi karakter tokoh anak laki-laki dan perempuan di dalam novel-novel karya mereka. Observasi awal inilah yang melatarbelakangi peneliti untuk menggali lebih dalam lagi mengenai konstruksi gender seperti apa yang terdapat dalam novel-novel anak karya penulis anak di Indonesia.

Penelitian ini mengkaji enam novel anak karya enam penulis anak di Indonesia. Tiga di antara keenam penulis itu adalah perempuan, yakni Alline (Millie Sang Idola, 2006), Muthia Fadhila Khairunnisa (Little Balerina, 2011), dan Sekar Maya I Love Cooking, 2010). Tiga penulis novel anak yang berjenis kelamin laki-laki antara lain RM Hanif Sulthoni (My Amazing Adventure, 2012), Detektif Naga Bonar karya Pahrul Mu lia (2013), dan Ali Riza (Kisah Tiga Pengembara, 2005). Dengan mengeksplorasi dan mengetahui bagaimana identitas, relasi, serta peran yang terefleksi dalam keenam novel anak karya penulis anak di Indonesia tersebut di atas, maka dapat diketahui bagaimana gender yang terkonstruksi dalam masyarakat direfleksikan oleh anak-anak di dalam karya sastra.

Penelitian ini bertujuan menelaah dan menemukan konstruksi gender yang terlihat dalam identitas gender, peran gender, dan relasi gender yang terdapat dalam novel-novel anak di Indonesia. Untuk mencapai tujuan ini, diperlukan serangkaian kegiatan terhadap objek kajian, yakni novel anak, yang telah dipilih secara purposive random sampling, untuk kemudian dianalisis dengna menggunakan kerangka pembacaan kritik sastra feminis.

Di tingkat akademik, umumnya penelitian masih berupa penelitian kepustakaan dan menggunakan pendekatan strukturalis dan sifatnya deskriptif (Sarumpaet, 2010:57). Beberapa kampus yang tercatat mulai memasukkan kajian sastra anak untuk penelitian skripsi, tesis, atau disertasi antara lain UNY, UI, UNJ, dan Pusat Bahasa (Sarumpaet, 2010: 57 - 62). Beberapa penelitian terhadap sastra anak berkaitan dengan gender yang sudah pernah dilakukan antara lain Reaktualiasasi Cerita Anak-Anak: Eliminasi Kekerasan Terhadap Perempuan Dalam Media Anak-Anak Indonesia (Sendjaja dkk, 2003), Masculinites in Colonial Indonesian's Children Literature (Wulan, 2009), dan Ideologi anak ideal dalam lima Fiksi anak unggulan Indonesia Akhir Masa Orde Baru (Studi Kasus tentang Fiksi-fiksi Pemenang Sayembara Penulisan Naskah Fiksi Anak Depdiknas dan Penerima Penghargaan Buku Bacaan Anak Nasional Tahun 1996-2001) (Purbani, 2009). Namun, penelitian yang berkaitan dengan konstruksi gender dalam novel-novel anak karya penulis anak di Indonesia belum banyak dilakukan.

Persoalan sastra anak dan feminisme menjadi kajian Sendjaja, dkk dalam penelitiannya yang berjudul Reaktualiasasi Cerita Anak-Anak: Eliminasi Kekerasan terhadap Perempuan dalam Media Anak-Anak Indonesia (2003). Dari hasil analisis yang telah dilakukan, Sendjaja dkk menyimpulkan bahwa dalam cerita anak-anak dalam berbagai majalah anak-anak yang diteliti ternyata memuat perilaku kekerasan personal secara fisik, psikologis, seksual, dan finansial terhadap tokoh perempuan. Kekerasan semacam itu juga ditangkap oleh pembaca anak-anak. Secara kultural, 
ke-kerasan terhadap perempuan dijumpai pada pemberian peran terbatas sebagai pelaksana fungsi reproduksi di rumah sebagai ibu rumah tangga. Ditengarai ideologi patriarki berada di balik semua bentuk kekerasan terhadap perempuan tersebut.

Selain itu, hasil penelitian Sendjaja dkk membuktikan bahwa keinginan para pengelola media anak-anak untuk menjadikan majalah mereka sebagai basis panduan nilai-nilai moralitas tertentu bagi anak-anak, entah disadari atau tidak, telah menempatkan informasi yang berisi kekerasan terhadap perempuan melalui berbagai cerita yang mereka muat sebagai komoditas industri tersendiri. Peningkatan bentuk-bentuk kekerasan tertentu terhadap perempuan mengindikasikan akan kepentingan ekonomis tersebut. Dengan lain perkataan, visi kultural para pengelola media anak-anak itu ternyata kalah dengan kepentingan ekonomi politik untuk menjual komoditas informasi yang makin melanggengkan kepentingan ideologi kapitatlisme.

Persoalan maskulinitas dalam sastra anak Indonesia zaman kolonial diangkat oleh Wulan dalam ringkasan hasil penelitian disertasinyanya, "Masculinites in Colonial Indonesian's Children Literature", yang dimuat dalam jurnal explusultra vol 1, September 2009. Wulan menyoroti bagaimana gagasan menjadi seorang lelaki digambarkan dalam bacaan untuk anakanak yang diterbitkan oleh Balai Pustaka. Balai Pustaka dinilai berperan penting dalam mendirikan bacaan anak. Wulan menyoroti beberapa novel yang terbit di era Balai Pustaka, yakni Anak Desa (1930) dan Si Doel Anak Betawi (1936), dan Anak Nelajan (1930) karya Sidi Haroen. Ketiga penulis itu berasal dari Minang, yang menurut Wulan memiliki peran penting dalam membentuk cerita novel tersebut.

Cerita-cerita anak terbitan Balai Pustaka menurut Wulan diilhami oleh cerita Barat, misalnya Tom Sawyer (Si Samin dan
Si Doel Anak Betawi), Oliver Twist (Si Djamin dan Si Djohan). Kesamaan dari karya-karya itu adalah adanya identitas maskulinitas dalam tokoh protagonis (Wulan, 2009:17). Selain identitas maskulin dalam sastra anak terbitan Balai Pustaka, Wulan juga menemukan bahwa identitas tersebut ditemukan dalam sastra anak berbahasa Jawa, antara lain Kantja Anjar dan Botjah ing Goenoneng karya M Soeratman Sastradiarja (1928 dan 1929), dan Tig lan Tor karya Sasrasoetiksna (1919). Kesamaannya terletak pada tokoh protagonis, seting, dan penggunaan bahasa (2009:12) yang menggambarkan aristokrasi priyayi Jawa, dengan adanya hirarki bahasa. Dalam Tig lan Tor, ceritanya berpusat pada seorang priyayi muda yang memiliki kawan seorang penggembala ternak, yang disebut Bocah Angon. Bocah Angon ini adalah "The Other" bagi Tig dan Tor.

Penelitian Purbani (2009) dilakukan terhadap lima fiksi anak unggulan Indonesia yang lahir pada masa akhir Orde Baru berjudul Pulau Sangia Penuh Misteri, Kabul Murungkayu, Si Perung, Tiga Sekawan di Rimbu Belantara dan Raja Kate Dikepung Asap. Kelima fiksi tersebut merupakan pemenang sayembara penulisan naskah fiksi anak Depdiknas sekaligus penerima penghargaan buku bacaan anak nasional tahun 1996-2001. Penelitian Purbani juga memeriksa wacana tentang pendidikan, tentang anak dan sastra anak yang berkembang pada masa Orde Baru.

Penelitian ini menemukan bahwa lima teks yang diperiksa mengandung ideologi perferksionisme, yakni ideologi yang menempatkan anak-anak sebagai the perfect hero yang ditunjukkan dengan penggambaran anak-anak yang memiliki watak-watak bertakwa, pandai, berbudi pekerti, berjiwa kebangsaan, pemberani, cinta alam dan lingkungan, berjiwa kepemimpinan, dan pada akhirnya dinobatkan menjadi pahlawan. Anak-anak yang diidealkan dalam teks ini juga hidup dalam ideologi-ideologi paternalisme, 
patriarki dan instanisme yang menempatkan anak-anak dalam perlindungan kaum dewasa, merayakan kebebasan anak laki-laki, meminggirkan anak perempuan dan membiarkan anak-anak tanpa proses menjadi.

Dari beberapa tinjauan terhadap kajian sastra anak yang telah dilakukan, dapat diperoleh gambaran bahwa sastra anak menyimpan problematika yang cukup beragam, dan membutuhkan peran ilmu sastra untuk membedah dan memaknai serta memanfaatkannya dalam kehidupan praktis. Mengingat kajian gender atas sastra anak Indonesia belum begitu banyak dilakukan, maka perlu dilakukan penelitian yang relevan dengan permasalahan tersebut. Atas pertimbanganpertimbangan itu, peneliti merasa perlu melakukan kajian gender terhadap novel anak Indonesia, khususnya novel anak yang ditulis oleh penulis anak di Indonesia. Penelitian mengenai persoalan gender dan konstruksinya di dalam novel-novel karya penulis anak sejauh ini belum terlalu banyak dilakukan.

\section{METODE}

Objek material penelitian ini adalah 6 (enam) novel anak yang diterbitkan oleh penerbit Dar! Mizan, dalam bendera Kecil-Kecil Punya Karya. Keenam novel itu adalah Millie Sang Idola karya Alline (2006), Little Balerina karya Muthia Fadhila Khairunnisa (2011), I Love Cooking (2010) karya Sekar Maya, My Amazing Adventure karya RM Hanif Sulthoni (2012), Detektif Naga Bonar karya Pahrul Mulia (2013), dan Kisah Tiga Pengembara karya Ali Riza (2005). Objek formal penelitian ini adalah segala permasalahan yang terkait dengan kontruksi gender, yakni: (1) identitas gender dalam novel anak karya penulis anak di Indonesia; (2) peran gender dalam novel anak karya penulis anak di Indonesia; dan (3) relasi gender dalam novel anak dalam novel anak karya penulis anak di Indonesia.
Jenis penelitian ini adalah deskriptif kualitatif. Penelitian ini berjenis deskriptif kualitatif karena data-data yang dikumpulkan dalam penelitian ini adalah data verbal berupa kutipan kata-kata, frase, paragraf, atau wacana (Moleong, 2006:11; Given, 2008:186). Teknik deskriptif kualitatif dilakukan dengan tahapan sebagai berikut: (1) membaca dan mengklasifikasikan data berdasarkan rumusan permasalahan yang terkait dengan persoalan identitas, relasi, dan peran gender dalam objek penelitian; (2) melakukan kategorisasi dan tabulasi berdasarkan permasalahan serta memaknainya; dan (3) melakukan inferensi berdasarkan kerangka teori kritik sastra feminis, yakni membaca sebagai perempuan (women as a reader).

\section{HASIL DAN PEMBAHASAN Identitas Gender dalam Novel Anak Karya Penulis Anak di Indonesia}

Identitas gender yang ditemukan dalam keenam novel yang dikaji adalah gambaran kepatuhan akan heteronormativitas yang berlaku di masyarakat. Tokoh perempuan biasanya digambarkan berkarakter feminin; penuh kelembutan, kasih sayang, halus perilakunya, memiliki ketulusan dalam pengabdian, penuh tanggung jawab dalam tugas-tugas domestiknya.

Tokoh laki-laki dalam novel yang dikaji umumnya digambarkan sebagai manusia yang memiliki keunggulankeunggulan, seperti bertanggung jawab, memiliki jiwa kepemimpinan, memiliki hobi dan pekerjaan yang menunjukkan sisi maskulinitasnya. Selain kedua kualitas karakter yang dapat dibedakan secara bipolar, ternyata ditemukan tokoh dengan karakter yang berada di antara keduanya: memiliki karakter yang setara dengan identitas maskulin sekaligus feminin. Berikut adalah pembahasan secara lengkapnya. 
Tokoh perempuan dalam novel yang dikaji dapat dibedakan menjadi dua, mereka yang berada dalam usia kanakkanak dan perempuan dewasa. Anak perempuan biasanya berperan menjadi tokoh murid dalam cerita, sedangkan perempuan dewasa berperan menjadi ibu atau guru. Tokoh perempuan dewasa yang berperan sebagai guru dapat ditemui dalam novel Little Balerina, sedangkan tokoh perempuan dewasa lainnya yang berperan sebagai ibu dapat ditemui dalam novel Millie Sang Idola, My Amazing Adventure, Detektif Naga Bonar, dan Little Balerina.

Tokoh perempuan yang berperan sebagai guru dan ibu memiliki identitas feminin yang sangat kuat. Tokoh Mrs. Vlarinna, misalnya, adalah seorang guru perempuan yang memiliki kualitas feminin dengan perwatakannya yang lemah lembut. Berikut adalah gambaran identitas gender dari Mrs. Vlarinna.

Setelah acara puncak selesai, Mrs. Vlarinna berpidato, "My Golden Children, please welcome our new friend $i$ want on grade $V$-B. Calline Hoona Emmody Rabellarotcha! And, after this event, you will be free to go around here. But, you need to obtain permission from Ms. Lollyred if you want to go out from here. Okay?"

“Okay, Mrs. Vlarinna!" koor anakanak. (Little Balerina, hlm. 51)

Mrs. Vlarinna adalah gambaran seorang guru dengan karakter feminin yang kuat. Sifatnya hangat, penyayang kepada anak, memperhatikan segala kebutuhan mereka, dan dicintai oleh anak-anak karena sikapnya tersebut.

Identitas feminin yang kuat terutama dijumpai dalam tokoh-tokoh yang berperan sebagai ibu. Hampir semua ibu dalam novel yang dikaji, seperti Millie Sang Idola, My Amazing Adventure, Detektif Naga Bonar, Little Balerina selalu menjadi perempuan-perempuan teladan dalam rumah tangga mereka.
Tokoh Ibu dalam novel Detektif Naga Bonar, misalnya, identitas femininnya dapat dijumpai dalam karakternya yang memiliki semangat keibuan, serta ketulusan untuk melayani suami dan anaknya, seperti yang tampak dalam kutipan berikut.

Malam ini aku dan ibu juga ayah sedang berkumpul di ruang makan. Kami makan bersama dan doa dipimpin oleh ayah. Ibu memasak ikan hasil pancingan ayah tadi di sungai bersama ayahnya bonar. Pasti Bonar juga sedang memakan ikan di rumahnya, pikirku.Aku tersenyum sendiri. (Detektif Naga Bonar, hlm. 51)

Identitas feminin seorang tokoh ibu juga ditemui dalam novel My Amazing Adventure. Identitas gender tokoh ibu ditunjukkan dengan kepiawaiannya untuk memasak, menyiapkan makanan bagi suami dan anak-anak mereka.

Biasanya, ibu sering memasak spageti untuk Rudy ketika Rudy sedang mandi. Cara membuatnya sangat mudah. Pertama, ibu merebus spageti hingga lunak. Setelah lunak, spageti ditiriskan dan diberi saus. Lalu ditaburi keju, potongan daging, dan yang terakhir daun seledri. Setelah selesai, ibu menghidangkannya di atas meja. (Detektif Naga Bonar, hlm. 14)

Selain kualitas identitas yang dianggap sebagai keunggulan seorang perempuan, ada salah satu novel yang menunjukkan stereotip negatif terhadap kualitas gender perempuan. Stereotip negatif itu adalah pelabelan perempuan sebagai manusia yang gemar belanja. Pelabelan negatif ini muncul pada tokoh Croella yang gemar belanja dalam novel Millie Sang Idola.

Janie Frott (Croella Lavandruss Janie Haron). Ia agak bodoh, masa ditawari jadi model nggak mau? Harus Tanya sama Millie? Aneh betul! Suka belanja dan suka menyamar. (Millie Sang Idola, hlm. 9) 
Kontes kecantikan, seperti halnya dalam dunia modelling kerap dijadikan tolok ukur akan sejauh mana seorang perempuan menunjukkan nilai-nilai keperempuanannya. Dalam novel Millie Sang Idola, tokoh Croella dinilai aneh sebab dia tidak mau menjadi model. Namun di sisi lain, tokoh Croella ini memiliki penggambaran negatif dari seorang perempuan yang memiliki kegemaran belanja.

Tokoh laki-laki dalam keenam novel yang dikaji memiliki kualitas gender yang relatif sama. Mereka hobi melakukan aktivitas di luar rumah. Selain itu, karakternya menunjukkan kualitas seorang pemimpin. Tokoh Naga Saputra dalam novel Detektif Naga Bonar, misalnya. Dia memiliki hobi melakukan kegiatan di alam, sekaligus memiliki rasa tanggung jawab yang tinggi. Berikut adalah kutipan yang menunjukkan kualitas identitasnya tersebut.

Lebih enak bermain di pemantang sawah siang hari terik dan setelah itu memanjat pohon kelapa untuk meredakan rasa haus. Sering sih ibu kami memarahi kami karena Bonar sering jatuh saat menaiki pohon kelapa. Ujung-ujungnya aku yang akan selalu disalahkan karena selalu mengajak Bonar memanjat. Tapi aku tak pernah ambil pusing, kesalahan itu akan selalu kuulangi esok harinya. Aku dan Bonar akan terus bermain setiap hari, dan bersama-sama melakukan hal-hal baru (Detektif Naga Bonar, hlm. 8)

Tokoh laki-laki yang memiliki kualitas gender yang bersahabat, gemar menolong, pandai, ditemui dalam novel yang berjudu Kisah Tiga Pengembara. Adalah Rannek dan Illius, tokoh pendekar dalam novel tersebut yang digambarkan memiliki kualitas gender yang sangat maskulin. Selain piawai dalam ilmu bela diri, mereka juga digambarkan memiliki keunggulan dibandingkan dengan pendekar perempuan.
Pendekar itu bergegas menuju dua kurungan tersebut. Dia merobohkan seorang Orc ke arah wanita berkulit ungu. Wanita itu merebut pisau milik Orc, lalu membunuhnya. Kemudian, wanita itu membebaskan diri dari kurungan. Si pendekar memandang wanita berkulit ungu itu dan mengharapkan ucapan terima kasih. (Kisah Tiga Pengembara, hlm. 13)

Selain tokoh Rannek dan Illius, tokoh laki-laki yang memiliki kualitas maskulin nampak sangat kuat dalam tokoh Lee dan Siro dalam novel I Love Cooking. Tokoh Lee digambarkan sangat menguasai dunia permainan laki-laki, seperti piawai menguasai permainan sepak bola dan voli, serta banyak disukai perempuan. Tokoh Siro bahkan digambarkan memiliki karakter yang dingin, 'cool' sehingga membuat banyak anak perempuan tergila-gila kepadanya.

Stereotip negatif dari laki-laki muncul dalam novel Little Balerina melalui tokoh Pak Kopsali dan Pak Sonsa. Pak Kopsali adalah kepala sekolah yang galak, sedangkan Pak Sonsa adalah seorang guru pelajaran IPS yang suka menyuruhnyuruh muridnya. Karakter yang muncul pada Pak Kopsali dan Pak Sonsa adalah gambaran superioritas laki-laki terhadap perempuan.

"Cher, tolong tuliskan di papan tulis paragraph 1 sampai 4, bab 5," ujar pak Sonsa, guru IPS.

Dengan lesu, cher menuliskan apa yang diperintahkan Pak Sonsa. Hu-uh, kalimatnya ribet-ribet. Pelajarannya enggak ada yang penting.Kenapa, sih, harus ada pelajaran IPS? pikir Cher dalam hati sambil menuliskan paragraf 1 sampai 4 , bab 5 di papan tulis. (Little Balerina, hlm. 17)

Pak Kopsali kepala sekolah datang. Brak! Pintu ruang senam dibuka pak Kopsali dengan galak. Cher dan Emmy seger melarikan diri. Tapi... 
oooh...mereka berdua tertangkap basah oleh Pak Kopsali.

"Ikut Bapak ke kantor!" ujar beliau. (Little Balerina, hlm. 20)

Selain bipolarisme identitas gender feminin dan maskulin, ditemukan juga identitas yang berada di antara ke duanya. Identitas tersebut muncul dalam tokoh anak perempuan Cher dan Izumi yang tomboy. Cher adalah tokoh perempuan yang tomboy dalam novel Little Balerina, sedangkan Izumi adalah tokoh perempuan yang tomboy dalam novel I Love Cooking.

Cher digambarkan sebagai anak yang enerjik, sedangkan Izumi sebagai anak perempuan yang jago dalam kegiatan olah raga, baik hati, dan disegani oleh kawan laki-lakinya. Berikut adalah gambaran tokoh Cher dan Izumi.

Calline Hoona Emmody Rabellarotcha (Cher). Anak tomboi ini dulu sangat tidak suka balet. Dia tidak suka saat mamanya mengajak dia ke pertunjukan balet. Cher agak susah diatur. Maklum, tomboi. Tapi, smua berubah saat Chet pindah sekolah. (Little Balerina, hlm.11)

Izumi adalah temanku yang kaya. Dia hobi makan permen karet. Kehebatannya bermain alat musik sudah tidak bisa diragukan lagi. Dia ikut klub tenis, basket, drum band, dan judo di sekolah. Izumi adalah anak yang tomboy. Musuh besarnya Shiro. Terkadang, dia sombong. Tetapi, dia anak yang baik, kok! (I Love Cooking, hlm. 10)

\section{Peran Gender dalam Novel Anak karya Penulis Anak di Indonesia}

Setting cerita dalam keenam novel yang dikaji umumnya berlangsung di sekolah/asrama siswa. Dengan demikian, baik laki-laki dan perempuan memiliki peran yang sama di sektor publik. Namun, masih ditemukan juga tokoh perempuan yang hanya berperan di sektor domestik. Misalnya, tokoh ibu dalam keenam novel yang berperan besar dalam pengasuhan dan perawatan anak, dan melayani suami atau anak-anak mereka. Tokoh perempuan yang berada di sektor publik antara lain ditunjukkan dalam berprofesi sebagai guru.

Peran perempuan di sektor domestik ditunjukkan dengan kegiatan-kegiatan yang berkisar pada pelayanan terhadap anak-anak dan suami, kegiatan memasak untuk keperluan mereka, berbelanja, mengasuh dan merawat anak-anak, serta memastikan keluarga mereka terlayani dengan baik. Inilah kiranya yang membuat perempuan ditempatkan sebagai angels of the house dalam masyarakat patriarkis apabila mereka berhasil menjalankan tugas-tugas domestik dengan baik.

Figur angels of the house muncul dalam tokoh-tokoh perempuan, khususnya yang berperan sebagai ibu dalam cerita. Figur angels of the house ini muncul dalam semua novel. Artinya, penulis anak dalam novel yang dikaji masih membawa nilai-nilai tradisional gender lama yang mengarahkan perempuan kepada idealisme peran, yakni rumahtangga.

Hal ini sejalan dengan ideologi ibuisme (Suryakusuma, 2010:39) yang dianut dan dibesarkan dalam rezim Orde Baru di Indonesia. Perempuan-perempuan mengalami housewifization atau pengiburumahtanggaan dengan menyerahkan seluruh tanggung jawab rumah tangga kepada seorang perempuan (ibu, isteri). Tampaknya ini pula yang dibawa oleh penulis-penulis novel dalam karyanya.

Tokoh ibu yang merupakan gambaran keberhasilan pengiburumahtanggan muncul dalam novel Detektif Naga Bonar, My Amazing Adventure, dan Little Balerina. Tokoh ibu dalam ketiga novel itu sangat piawai melayani kebutuhan anak-anak dan suami mereka. Mulai dari memasak, berbelanja, hingga melayani makan dan memastikan kebutuhan mereka tercu- 
kupi. Tak lupa pula, dengan mencurahkan segala perhatian dan kasih sayangnya untuk seluruh anggota keluarga.

Malam ini aku dan ibu juga ayah sedang berkumpul di ruang makan. Kami makan bersama dan doa dipimpin oleh ayah. Ibu memasak ikan hasil pancingan ayah tadi di sungai bersama ayahnya bonar. Pasti Bonar juga sedang memakan ikan di rumahnya, pikirku. Aku tersenyum sendiri. (Detektif Naga Bonar, hlm. 9)

Biasanya, ibu sering memasak spageti untuk Rudy ketika Rudy sedang mandi. Cara membuatnya sangat mudah. Pertama, ibu merebus spageti hingga lunak. Setelah lunak, spageti ditiriskan dan diberi saus. Lalu ditaburi keju, potongan daging, dan yang terakhir daun seledri. Setelah selesai, ibu menghidangkannya di atas meja. (My Amazing Adventure, hlm. 14)

"Ayo, Cher! Cepat siap-siapnya, dooong," ujar mama.

"Huuuh. Iya, Maaa..." Dengan lesu, Cher mengambil handuknya lalu segera mandi.

"Ayo semangat, dong! Jangan lesu begitu. Kan kita mau menonton pertunjukan balet. Ayo, dooong!" Mama memberi semangat kepada Cher yang lesu. (Little Balerina, hlm. 10)

Selain berada di ranah domestik, ada pula tokoh perempuan yang di ranah publik. Mereka berprofesi sebagai guru, seperti dalam novel Little Balerina. Namun, peran sebagai guru masih saja membawa peran-peran gender perempuan dalam ranah domestik. Sebab, seorang guru pastilah menjadi 'perawat, pengasuh, pendidik' anak-anak mereka.

Secara fungsional, guru masih menjalankan peran-peran perawatan, pengasuhan, pendidikan, seperti halnya perempuan di ranah domestik pada umumnya. Justru mereka yang berada di ranah publik ini mengalami double burden. Sebab, selain bertanggung jawab di ranah publik, mereka harus bertanggung jawab pula di ranah domestik. Dalam novel yang dikaji, kehidupan guru di ranah domestik mereka tidak diceritakan. Namun dalam kenyataan di masyarakat, mereka ini menjalani peran ganda.

\section{Relasi Gender dalam Novel Anak Karya Penulis Anak di Indonesia}

Relasi gender yang ditemukan dalam novel anak karya penulis anak di Indonesia cukup beragam. Bentuk-bentuk relasi ini ditentukan oleh berbagai macam faktor, misalnya: usia, hubungan dengan orang dewasa, status ekonomi dan sosial budaya.

Bentuk relasi yang koordinat muncul manakala seorang tokoh anak-anak perempuan dan laki-laki bermain dengan teman sebayanya. Relasi yang sifatnya koordinatif dengan teman sebaya ini muncul di semua novel yang dikaji. Hubungan yang koordinatif antarteman sebaya ini dikarenakan kesamaan usia. Kesamaan usia cenderung melahirkan hubungan yang egaliter dan koordinatif, bukan subordinat ataupun superordinat.

Hubungan yang subordinatif atau superordinatif antar teman sebaya biasanya terjadi karena adanya perbedaan kelas sosial, seperti yang ditemukan dalam novel Little Balerina. Dalam novel ini, diceritakan adanya tokoh bernama Siti Adiffa, seorang pemulung yang selalu melihat anak-anak sekolah balet berlatih. Oleh Mrs. Vlarinna, gadis pemulung ini kemudian diikutsertakan dalam kelas menari balet mereka.

Respon berbeda justru muncul dari murid-murid Mrs. Vlarinna. Cher, Emily, Daniella merasa gadis pemulung itu tidak layak untuk berada bersama mereka di sekolah balet. Selain itu, mereka merasa kelas mereka lebih tinggi daripada Siti Adiffa, yang ternyata justru memiliki kepandaian menari lebih baik 
daripada mereka. Ini terbukti, ketika dalam pertandingan balet antarsekolah, justru Siti Adiffa yang menjadi juara satu, bukan Cher yang selalu diunggulkan oleh rekan-rekannya.

Pandangan merendahkan Cher dkk terhadap Siti Adiffa karena perbedaan kelas sosial ekonomi terlihat dalam kutipan berikut.

Selama latihan, ada seorang pemulung yang mengintip di jendela. Cher risih dengan keadaan pemulung kecil itu. Bajunya kumuh, hanya dress putih yang sudah tidak bisa dibilang putih lagi. Sambil melihat, pemulung kecil itu juga mempraktikkan pointe. Apa, sih, mau dia?

"Eh, Anischa, lihat, deh, pemulung itu! Aku risih sama dia," bisik Cher kepada Anischa.

"Iya, ya! Pakai mempraktikkan pointe segala pula! Kayak dia bisa aja," komentar Anischa. Cher mengangguk. (Little Balerina, hlm.82)

Terhadap orang dewasa, relasi tokoh dengan mereka memiliki dua bentuk. Pertama, relasi yang koordinatif. Kedua, subordinatif. Relasi yang koordinatif ini muncul karena sikap guru yang terbuka dan hangat kepada anak-anak. Meski guru cenderung bersikap terbuka, namun anak-anak tetap menghormati mereka. Relasi ini tergambar dalam novel Little Balerina. Guru-guru di sekolah mereka, seperti Miss Jully, bersikap hangat. Dia tidak memarahi anak-anak yang tidak sengaja melakukan kesalahan.

Mereka berlari sekencang-kencangnya. Tiba-tiba, bruk! Cher menabrak Miss Jully yang sedang membawa tiga buah kaset.

"Aduuuh....mm....maaf, Miss.... Sss...saya enggak seng...sengaja...," ucap Cher terbata-bata.

"Okay. Enggak apa-apa." Miss Jully tersenyum. "But, you have to be careful. Promise?"

"Promise!" janji Cher. "Oh, iya, Miss, may I borrow your casette?"

"Sure. Don't forget to bring it to me, tomorrow!" Miss Jully segera meninggalkan mereka. (Little Balerina, hlm. 69)

Mrs Vlarinna, misalnya, selalu menyapa anak didiknya dengan 'my Golden Children'. Sapaan 'my golden children' ini menyaratkan kasih sayang, persahabatan, dan rasa bangga Mrs Vlarinna terhadap murid-muridnya.

"Morning, My Golden Children," sapa Mrs. Vlarinna.

"Morning, Mrs. Vlarinna," jawab semua murid.

"Hari ini, saya akan memberikan pemberitaan tentang perlombaan balet yang diadakan oleh D'Queen Dancers Community. Jadi, saya akan memilih lima murid tingkat, six, five, dan four yang nanti akan mewakili Emerald Balerina's Dancing College mengikuti lomba itu." (Little Balerina, hlm. 92)

Sebaliknya, guru-guru yang tidak seperti Miss Jully atau Miss Vlarinna yang hangat, terbuka, dan bersahabat, ditemukan pula dalam novel Little Bale-rina. Miss Zue, misalnya, digambarkan sebagai guru yang galak dan tidak sabaran kepada murid-muridnya. Anak-anak kurang memiliki kedekatan dengan Miss Zue karea sifatnya yang galak ini.

Murid-murid menahan split mereka. Beberapa anak - termasuk Cher dan Anischa- mulai mengeluh.

“Tujuh...delapan...selesai!” seru Miss Zue.

Murid-murid lega.

"Kalian ini! Delapan hitungan saja tidak bisa! Gimana mau split selama satu jam?" geram Miss Zue.

Brak! Miss Zue keluar kelas. 
"Aduh! Marah besar, nih, Miss Zue!" bisik Cher kepada Anischa.

"Hah?" beberapa teman di sekitar Anischa kaget. (Little Balerina, hlm. 63)

Selain hubungan subordinatif yang ditunjukkan dalam interaksi antara guru dan murid, hubungan tersebut juga ditunjukkan manakala anak-anak berinteraksi dengan orang tua. Ini biasanya disebabkan oleh faktor keturunan. Anak-anak akan cenderung menghormati orang tua mereka. Karena bentuk penghormatan ini, maka sikap relasi yang muncul adalah subordinatif. Gambaran ini terlihat dalam novel Detektif Naga Bonar.

Namun, aku dan Bonar sahabat karibku itu hanya bisa berlarian dan bermain di sana. Lebih enak bermain di pematang sawah siang hari terik dan setelah itu memanjat pohon kelapa untuk meredakan rasa haus. Sering sih ibu kami memarahi kami karena Bonar sering jatuh saat menaiki pohon kelapa. Ujung-ujungnya aku yang akan selalu disalahkan karena mengajak Bonar memanjat. (Detektif Naga Bonar, hlm. 6-7).

Ada perbedaan bentuk relasi yang cukup terlihat dalam novel-novel anak yang dikaji. Dalam novel yang settingnya di pedesaan, hubungan anak dan orang tua terlihat lebih berjarak daripada novel yang bersetting masyarakat perkotaan (dan cenderung metropolitan) dan berkelas sosial ekonomi menengah ke atas. Dalam novel Millie Sang Idola dan I Love Cooking, misalnya, hubungan antara anak dan orang tua mereka lebih cenderung hangat, tak berjarak, tampak bersahabat dan dekat.

\footnotetext{
“Papa!" seruku.

"Ya!" papa berjalan mendekatiku.
}

"Apakah mama pernah mengarang buku?" tanyaku sambil memberikan buku yang kupinjam.

Papa melihat buku itu. "Ya, dia pernah mengarang buku. Bukunya sangat laris!" jawab papa.

"Kenapa papa tidak pernah memberitahuku? Ya, sudah deh! Terima kasih, Pa!" aku langsung berlari meninggalkan papa. Aku pergi ke kamarku dan membaca buku itu. Di dalamnya, tertulis bagaimana cara memasak yang baik dan ada resepresep yang pernah dibuat mama. Saat itu, aku membaca resep yang sangat menarik. (I Love Cooking, hlm.92)

Dari bahasan mengenai relasi gender anak terhadap tokoh lain dalam novel, dapat diketahui bahwa relasi gender dipengaruhi oleh beberapa faktor. Faktor tersebut antara lain usia, hubungan kekerabatan, sosial ekonomi, dan budaya. Faktor psikologis orang tua juga memengaruhi relasi yang terjalin antara anak dan orang tua. Terhadap orang tua/orang dewasa yang cenderung galak, anakanak akan menjaga jarak dengan mereka. Sehinga, relasi yang tercipta adalah anak-anak akan bersubordinatif dengan mereka. Sebaliknya, apabila orang dewasa atau orang tua bersifat hangat, bersahabat, dan terbuka kepada anak-anak, maka relasi yang tercipta adalah relasi yang koordinatif, tanpa menghilangkan batasbatas menghargai seorang anak kepada orang dewasa lainnya.

\section{SIMPULAN}

Novel-novel anak karya penulis anak di Indonesia belum semuanya menggambarkan keadilan gender. Tokoh-tokohnya bahkan mengalami stereotipisasi karakter gender. Lelaki hampir selalu digambarkan sebagai tokoh yang kuat, cerdas, mandiri. Sedangkan tokoh perempuan, hampir selalu digambarkan sebagai perempuan yang cantik, lemah lembut, 
keibuan, penyayang, dan memiliki sisi negatif lainnya seperti gemar belanja, suka menggosip, cerewet, dan emosional. Tokoh yang memiliki dua karakter, feminin dan maskulin, digambarkan segai tokoh yang aneh sekaligus memiliki keunggulan karakter dibandingkan tokoh perempuan atau lelaki lainnya.

Ada ketidakseimbangan dalam pembagian peran gender dalam novel-novel anak karya penulis anak di Indonesia. Tokoh perempuan memiliki peran gender di sektor publik dan domestik, sedangkan tokoh laki-laki hanya berperan di sektor publik. Selain memiliki akses di ruang publik (misal, dengan menjadi pengajar bagi tokoh perempuan dewasa, atau murid bagi tokoh perempuan anak-anak), tokoh perempuan tetap memiliki peranan di sektor domestik. Peran tokoh perempuan di sektor domestik lekat dengan kegiatan memasak, perawatan anak, dan tugastugas rumah tangga lainnya (membersihkan rumah, mencuci, melayani suami, atau saudara lelaki).

Bentuk relasi yang tercipta dalam novel-novel anak karya penulis anak di Indonesia menunjukkan pola yang cukup vareatif, namun dapat dikenali. Kepada orang dewasa, tokoh anak-anak umumnya akan mengalami relasi subordinatif terhadap mereka. Namun, relasi yang koordinatif kadang juga tercipta, umumnya kepada mereka yang mau bersikap terbuka atau ramah kepada tokoh anak-anak. Terhadap rekan sebaya, relasi yang muncul juga beragam. Terhadap rekan yang kelas sosial ekonominya lebih rendah, umumnya relasi yang akan ditemui cenderung tidak seimbang (bersifat superordinatif atau subordinatif). Terhadap rekan yang berlainan jenis, sifat yang muncul ada dua macam, subordinatif dan superordinatif. Relasi subordinatif muncul dari tokoh anak laki-laki terhadap rekan mereka yang sebaya. Sebaliknya, relasi yang superordinatif justru ditunjukkan oleh tokoh anak laki-laki dan perempuan terhadap rekan perempuan mereka yang memiliki kualitas tomboy.

\section{UCAPAN TERIMA KASIH}

Artikel ini disarikan dari Program Penelitian Desentralisasi BOPTN yang dilaksanakan di Fakultas Bahasa dan Seni dengan anggaran dana DIPA UNY tahun 2014. Ucapan terima kasih kami sampaikan kepada LPPM UNY yang telah memfasilitasi penelitian ini hingga selesai. Ucapan terima kasih juga kami sampaikan kepada reviewer yang telah mengoreksi dan memberi masukan terhadap artikel ini.

\section{DAFTAR PUSTAKA}

Alline. 2007. Millie Sang Idola. Bandung: Dar! Mizan.

Given, L.M. 2008. The SAGE Encyclopedia of Qualittative Research and Method Vol. 1 $\mathcal{E} 2$. New York: SAGE Publications.

Khairunnisa, M.F. 2011. Little Balerina. Bandung: Dar! Mizan.

Moleong. 2006. (cet. ke-20). Metodologi Penelitian Kualitatif (Edisi Revisi). Bandung: Rosda Karya.

Mulia, Pahrul. 2013. Detektif Naga Bonar. Jakarta: Zetu.

Purbani, W. 2009. “Ideologi Anak Ideal dalam Lima Fiksi Anak Unggulan Indonesia Akhir Masa Orde Baru (Studi Kasus Tentang Fiksi-Fiksi Pemenang Sayembara Penulisan Naskah Fiksi Anak Depdiknas dan Penerima Penghargaan Buku Bacaan Anak Nasional Tahun 1996-2001)." Disertasi. Jakarta: Universitas Indonesia.

Riza, A. 2005. Kisah Tiga Pengembara. Bandung: Dar! Mizan.

Sarumpaet, R.K. Toha. 2010. Pedoman Penelitian Sastra Anak. Edisi Revisi. Jakarta: YayasanObor.

Sendjaja, S.D., dkk. 2003. "Reaktualiasasi Cerita Anak-Anak: Eliminasi Kekerasan Terhadap Perempuan dalam Media Anak-Anak Indonesia". Penelitian Hibah Bersaing, Program Pas- 
casarjana Ilmu Sosial dan Ilmu Politik Universitas Indonesia, Jakarta.

Sekar. 2010. I Love Cooking. Bandung: Dar! Mizan.

Sulthoni, H. 2012. My Amazing Adventure. Bandung: Dar! Mizan.
Suryakusuma, J. 2011. Ibuisme Negara: Konstruksi Sosial Keperempuan Orde Baru. Jakarta: Komunitas Bambu.

Wulan, N. 2009. “Masculinities in Colonial Indonesian Children's Literature". Dalam exPLUSultra vol 1 September 2009. WUN International Network. 